\title{
Pengaruh Penambahan Skim Terhadap Karakteristik Dadih Susu Sapi Yang Dibuat Dalam Ruas Bambu Wuluh (Schizostachyum silicatum) Di Bali
}

\author{
The Effect of Skim Addition on The Characteristics of Cow Milk Dadih Made in Wuluh Bamboo \\ (Schizostachyum silicatum) Tubes in Bali
}

\author{
Mariya Ulfa*, I Made Sugitha, Luh Putu Trisna Darmayanti \\ Program Studi Ilmu dan Teknologi Pangan, Fakultas Teknologi Pertanian, \\ Universitas Udayana, Jl. Raya Kampus Unud, Jimbaran, Kuta Selatan, Badung-Bali \\ *Email: ulfa.harun48@gmail.com
}

\begin{abstract}
This study aims to determine the effect of skim additional on the characteristics and the amount of the right skim additional of cow milk dadih made in wuluh bamboo (Schizostachyum bluneiness) tubes. The completely randomized design with 5 levels of skim addition treatment were : 4\%, 6\%, 8\%, 10\% and $12 \%$. The treatment was repeated 3 times for obtain 15 experimental units. The data were analyzed by variance, and the significant effect of the treatment was followed by Duncan. The additional of skim has effect to yield, water content, $\mathrm{pH}$, total acid, total microbes, total lactic acid bacteria (LAB) and has effect to scoring test of aroma, taste and overall acceptance by hedonic test, but doesn't significantly affect scoring test of color and texture. The addition of $10 \%$ skim produces the best characteritics with yield $65,31 \%$, water content $63,72 \%, \mathrm{pH} 5,50$, total lactic acid $1,31 \%$, total bacterial colony $4,38 \times 10^{9} \mathrm{CFU} / \mathrm{g}$, total lactic acid bacteria (LAB) 3,42 x $10^{9} \mathrm{CFU} / \mathrm{g}$, color cream, typical aroma of fermented milk, solid texture, sour taste and rather dislike on overall acceptance.
\end{abstract}

Keywords : Cow milk dadih, skim milk, wuluh bamboo

\section{PENDAHULUAN}

Dadih merupakan susu fermentasi asli dari Daerah Sumatera Barat, berwarna putih dengan konsistensi padat menyerupai tahu dan mempunyai rasa asam yang khas. Secara tradisional dadih dibuat dari susu kerbau yang diperam dalam tabung bambu dan ditutup dengan daun spisang, kemudian dibiarkan dalam suhu ruang $\left( \pm 30^{\circ} \mathrm{C}\right)$ selama 48 jam (Sugitha, 1995).

Menurut Usmiati dan Risfaheri (2012), karakteristik dadih berbeda-beda tergantung daerah produksinya. Dadih yang diproduksi di Kabupaten Agam dan Solok memiliki kandungan air $81,79-82,40 \%$, protein $6,91-7,06 \%$, lemak
7,98-8,17\%, total asam $1,28-1,32 \%$ dan $\mathrm{pH} 4,76-$ 4,80 (Sirait, 1993). Dadih yang dibuat dari susu sapi memiliki kandungan air $79,72 \%$, total asam $1,21 \%$, protein $4,7 \%$ ), lemak $5,1 \%$, pH 4,6 dan total koloni 1,78 x 105 CFU/g (Sugitha ,1995)

Fermentasi dadih dilakukan oleh mikroba yang berasal dari bambu, daun pisang dan susu (Yudoamijoyo, 1983). Menurut Alase (1994) ruas bambu mengandung sejumlah mikroba pembentuk asam laktat. Bakteri yang berperan dalam proses fermentasi dadih terdapat di dalam permukaan ruas bambu bagian dalam (Hosono, 1992). Jenis bakteri asam laktat yang diisolasi dari dadih yang dibuat dalam bambu dapat dilihat pada Tabel 1 . 
Tabel 1. Jenis bakteri asam laktat yang diisolasi dari dadih

\begin{tabular}{llll}
\hline Genus & Species & Genus & Species \\
\hline Lactobacillus & L. bevis & Lactococcus & L. lactis subsp. lactis, \\
& L. casei subsp. casei & & L. lactis subsp. Cremoris \\
& L. casei subsp. Rhamnosus & & L. casei subsp. Diacetylactis \\
Streptococcus & S.Faecalis subsp. liquifaciens & Leuconostoc & L. mesenteroides \\
\hline
\end{tabular}

Sumber : Usmiati dan Risfaheri (2013)

Salah satu susu yang berpotensi sebagai bahan baku dadih adalah susu sapi karena ketersediaannya yang banyak dan mudah diperoleh. Namun susu sapi padatannya lebih rendah dari susu kerbau yaitu $18 \%$, sedangkan susu sapi total padatannya hanya $10-12 \%$ (Setiyanto dkk., 2009). Oleh sebab itu, perlu ditambahkan bahan tambahan yang dapat meningkatkan padatan susu sapi yaitu skim (Usmiati dan Risfaheri, 2013).

Skim merupakan susu tanpa lemak dalam bentuk cair maupun bubuk, skim yang akan ditambahkan dalam pembuatan dadih adalah skim bubuk. Skim bubuk memiliki padatan hampir 100\%, sehingga dapat meningkatkan padatan susu sapi. Skim juga mengandung sejumlah laktosa dan potein yang diharapkan dapat melengkapi komposisi susu dalam proses fermentasi (Kumala dkk., 2004), sehingga skim dapat dijadikan sebagai bahan tambahan dalam pembuatan dadih susu sapi (Sugitha, 1995) agar dadih yang dihasilkan dapat menyerupai dadih yang dibuat dari susu kerbau. Berdasarkan hal tersebut, maka dilakukan penelitian penambahan skim pada proses pembuatan dadih susu sapi untuk mengetahui pengaruhnya terhadap karakteristik dadih susu sapi dan konsentrasi penambahan skim yang tepat.

\section{METODE PENELITIAN}

\section{Tempat dan Waktu}

Penelitian ini dilaksanakan di Laboratorium Pengolahan Pangan, Laboratorium Mikrobiologi Pangan, Laboratorium Analisis Pangan serta Laboratorium Rekayasa Proses dan Pengendalian Mutu, Fakultas Teknologi Pertanian, Universitas Udayana. Waktu pelaksanaan mulai bulan April sampai dengan bulan Agustus 2018.

\section{Bahan dan Alat}

Bahan-bahan yang digunakan dalam penelitian ini terdiri dari susu sapi pasteurisasi (Diamond) yang diperoleh di Carefour dan Hypermart, susu skim plain (Tropicana Slim) diperoleh dari Tiara Dewata, bambu wuluh diperoleh dari tempat penjual bambu di Jl. Tanah Lot Kediri Tabanan dan daun pisang diperoleh dari pasar Desa Munggu, aquades, $\mathrm{NaOH} 0,1 \%$, indikator PP 1\%, Plate Count Agar (PCA), de Man Rogosa and Sharpe Agar (MRSA), larutan $\mathrm{NaCl}$ 0,85\%, Larutan Pepton Water (PW).

Alat yang digunakan meliputi panci, gelas ukur, thermometer air, kompor, tabung gas, sendok, spatula, oven, cawan, pinset, desikator, timbangan analitik, magnetin stirrer, $\mathrm{pH}$ meter, Erlenmeyer, cawan petri, laminar flow, autoclave, tabung reaksi, rak tabung reaksi, mikro pipet, bunsen, 
kapas, batang bengkok, incubator, vortex dan tissue.

\section{Rancangan Percobaan}

Penelitian ini menggunakan rancangan acak lengkap (RAL) dengan perlakuan penambahan skim (S) yang terdiri dari 5 taraf yaitu : S1 (4\%), S2 (6\%), S3 (8\%), S4 (10\%), S5 (12\%). Masingmasing perlakuan diulang sebanyak 3 kali sehingga diperoleh 15 unit percobaan. Data yang diperoleh dari hasil penelitian dianalisis dengan sidik ragam (ANOVA) dan apabila perlakuan berpengaruh terhadap variabel maka dilanjutkan dengan uji Duncan (Gomez dan Gomez, 1995).

\section{Pelaksanaan Penelitian}

Pada proses pembuatan dadih menggunakan metode yang digunakan berdasarkan Ditjen Peternakan (1984) yang dimodifikasi. Proses pelaksanaan penelitian dimulai dengan persiapan alat dan bahan. Susu sapi dan skim diukur sesuai perlakuan. Susu dimasukkan ke dalam panci, ditambahkan skim dan diaduk sampai larut. Kemudian dipanaskan sampai suhu mencapai $60^{\circ} \mathrm{C}$ sambil diaduk agar homogen dan tidak mengendap. Susu didinginkan sampai suhu $30^{\circ} \mathrm{C}$ sambil diaduk agar tidak menggumpal. Disiapkan bambu yang masih utuh ruasnya kemudian dipotong ujung atasnya. Susu dimasukkan ditutup dengan daun pisang dan diikat menggunakan karet. Kemudian disimpan pada suhu ruang selama 48 jam.

\section{Parameter yang Diamati}

Adapun parameter yang diamati meliputi : rendemen (Coggins, 1991), kadar air menggunakan metode pengeringan (Sudarmaji dkk., 1997), pH (Hadiwijoyo, 2009), total asam metode titrasi (Wahyudi, 2006), total mikroba dan total bakteri asam laktat menggunakan metode sebar (Hadiwiyoto, 2009). Sifat sensoris meliputi warna, aroma, terstur dan rasa diuji menggunakan metode skoring sedangkan penerimaan keseluruhan menggunakan metode hedonik (Soekarto, 1985).

\section{HASIL DAN PEMBAHASAN}

Nilai rata-rata rendemen, kadar air, total asam dan $\mathrm{pH}$ dadih susu sapi dengan pelakuan penambahan skim dapat dilihat pada Tabel 2.

Tabel 2. Nilai rata-rata rendemen, kadar air, $\mathrm{pH}$ dan total asam dadih susu sapi yang dibuat dalam ruas bambu wuluh di Bali.

\begin{tabular}{ccccc}
\hline Perlakuan penambahan skim & Rendemen (\%) & Kadar Air (\%) & Total Asam (\%) & pH \\
\hline S1 (4\%) & $24,98 \mathrm{a}$ & $71,15 \mathrm{c}$ & $1,12 \mathrm{a}$ & $5,70 \mathrm{~b}$ \\
S2 (6\%) & $37,81 \mathrm{~b}$ & $69,45 \mathrm{bc}$ & $1,22 \mathrm{ab}$ & $5,70 \mathrm{~b}$ \\
S3 (8\%) & $51,64 \mathrm{c}$ & $65,77 \mathrm{bc}$ & $1,26 \mathrm{ab}$ & $5,60 \mathrm{~b}$ \\
S4 (10\%) & $65,31 \mathrm{~d}$ & $63,72 \mathrm{ab}$ & $1,31 \mathrm{ab}$ & $5,50 \mathrm{ab}$ \\
S5(12\%) & $78,37 \mathrm{e}$ & $59,78 \mathrm{a}$ & $1,36 \mathrm{~b}$ & $5,30 \mathrm{a}$ \\
\hline
\end{tabular}

Keterangan : huruf yang sama dibelakang nilai rata-rata menunjukkan perlakuan tidak berbeda nyata $(\mathrm{P}>0,05)$. 


\section{Rendemen}

Hasil uji ANOVA menunjukkan bahwa penambahan skim berpengaruh sangat nyata $(\mathrm{P}<0,01)$ terhadap rata-rata rendemen dadih susu sapi. Berdasarkan Tabel 2 rendemen tertinggi ditunjukkan pada perlakuan S5 yaitu $78,37 \%$, sedangkan rendemen terendah ditunjukkan pada perlakuan S1 yaitu 24,98\%. Penggumpalan susu merupakan proses yang menentukan rendemen dadih susu sapi. Rendemen dadih susu sapi semakin meningkat seiring dengan penambahan skim, karena skim mengandung protein (kasein) yang beperan penting dalam penggumpalan dadih. Selama proses fermentasi dadih menyebabkan menurunnya $\mathrm{pH}$ dan terlepasnya kalium fosfor dari kaseain sehingga terjadi penggumpalan.

\section{Kadar air}

Hasil uji ANOVA menunjukkan bahwa penambahan skim berpengaruh sangat nyata $(\mathrm{P}<0,01)$ terhadap rata-rata kadar air dadih susu sapi. Bedasarkan Tabel 2 kadar air, kadar air tertinggi ditunjukkan pada perlakuan S1 yaitu $71,15 \%$ bb sedangkan nilai terendah ditunjukkan pada perlakuan S5 yaitu 59,78\%bb. Penurunan kadar air dipengaruhi oleh perlakuan penambahan skim, semakin banyak skim yang ditambahkan meningkatkan padatan susu sapi, karena padatan yang semakin tinggi akan menurunkan kadar air.

Menurut Afriani (2008) kadar air dadih berkisar $69-73 \%$, begitu juga dengan pernyataan Sugitha (1995) bahwa dadih memiliki kadar air $79,2 \%$. Kadar air dadih yang dibuat dari beberapa daerah di Sumatera barat adalah 75-82,40\%.

\section{Total Asam}

Hasil uji ANOVA menunjukkan bahwa penambahan skim berpengaruh terhadap rata-rata total asam dadih susu sapi $(\mathrm{P}<0,05)$. Total asam tertinggi ditunjukkan pada perlakuan S5 yaitu $1,36 \%$, sedangkan total asam terendah ditunjukkan pada perlakuan S1 yaitu 1,12\%.

Semakin tinggi penambahan skim pada dadih susu sapi total asam juga semakin meningkat karena kandungan laktosa pada skim meningkatkankan ketersediaan nutrisi BAL untuk pertumbuhannya, sehingga aktivitas BAL meningkat dan asam laktat yang dihasilkan juga semakin banyak. Sesuai dengan pernyataan Legowo dkk. (2009) semakin banyak bakteri asam laktat membentuk asam laktat, maka semakin tinggi pula asam yang terbentuk.

\section{pH}

Hasil uji ANOVA menunjukkan bahwa penambahan skim berpengaruh terhadap rata-rata pH dadih susu sapi $(\mathrm{P}<0,05)$. Berdasarkan Tabel 2 $\mathrm{pH}$ tertinggi ditunjukkan pada perlakuan $\mathrm{S} 1$ yaitu 5,7 sedangkan terendah ditunjukkan pada perlakuan S5 yaitu 5,3. Hasil ini didukung berdasarkan penelitian Setiyanto (2009) dadih susu sapi memiliki kandungan $\mathrm{pH}$ 4,43-5,6. Menurut Rahman dkk. (1992) laktosa merupakan komponen utama pada susu yang digunakan oleh BAL sebagai sumber energi selama fermentasi. Semakin meningkatnya aktivitas BAL semakin banyak pula asam laktat yang dihasilkan sehingga meningkatkan kadar keasaman dan menurunkan $\mathrm{pH}$. Nilai rata-rata total mikroba dan total BAL dapat dilihat pada Tabel 3. 
Tabel 3. Nilai rata-rata total mikroba dan total BAL dadih susu sapi yang dibuat dalam ruas bambu wuluh di Bali.

\begin{tabular}{ccc}
\hline Perlakuan penambahan skim & Total mikroba $($ CFU/g) & Total BAL $($ CFU/g) \\
\hline S1 (4\%) & $3,98 \times 10^{10}$ & $2,96 \times 10^{8}$ \\
S2 (6\%) & $3,60 \times 10^{10}$ & $4,38 \times 10^{9}$ \\
S3 (8\%) & $3,98 \times 10^{10}$ & $5,64 \times 10^{9}$ \\
S4 (10\%) & $4,38 \times 10^{9}$ & $3,42 \times 10^{9}$ \\
S5 (12\%) & $3,68 \times 10^{10}$ & $2,78 \times 10^{9}$ \\
\hline
\end{tabular}

\section{Total Mikroba}

Hasil penelitian menunjukkan bahwa semakin tinggi penambahan susu skim total mikroba yang dihasilkan semakin menurun. Total mikroba tertinggi ditunjukkan pada perlakuan S1 dan S3 yaitu 3,98 x $10^{10} \mathrm{CFU} / \mathrm{g}$, sedangkan total mikroba terendah ditunjukkan pada perlakuan S4 yaitu $4,38 \times 10^{9} \mathrm{CFU} / \mathrm{g}$. Total mikroba dapat disebut sebagai tingkat kontaminan mikroba pada suatu produk. Uji total mikroba bertujuan untuk mengetahui tingkat kontaminasi pada dadih susu sapi baik selama fermentasi maupun kontaminasi udara saat penanganan dan proses kerja ujitotal mikroba. Selama proses fermentasi BAL pada dadih susu sapi, bakteri tersebut mampu mendominasi dari awal fermentasi sehingga menurunkan jumlah mikroba kontaminan (Koesoemawardani dkk., 2013)

\section{Total Bakteri Asam Laktat (BAL)}

Hasil penelitian menunjukkan bahwa semakin tinggi penambahan susu skim total BAL yang dihasilkan semakin tinggi. Pada tabel 3 total BAL tertinggi ditunjukkan pada perlakuan S3 yaitu $5,64 \times 10^{9} \mathrm{CFU} / \mathrm{g}$, sedangkan total $\mathrm{BAL}$ terendah ditunjukkan pada perlakuan S1 yaitu $2,96 \times 10^{8} \mathrm{CFU} / \mathrm{g}$. Semakin tinggi skim yang ditambahkan total BAL semakin meningkat hal ini dikarenakan skim mengandung laktosa yang merupakan komponen utama yang menjadi sumber nutrisi pertumbuhan BAL, sehingga semakin banyak skim yang ditambahkan semakin tinggi aktivitas BAL. Hal tersebut didukung pendapat Rahman dkk. (1992) adanya laktosa sangat mempengaruhi kecepatan pertumbuhan BAL.

\section{Uji Sensoris}

Uji sensoris pada dadih susu sapi dilakukan dengan uji skoring terhadap rasa, aroma, warna dan tekstur, serta uji hedonik terhadap penerimaan keseluruhan. Nilai rata-rata uji skoring terhadap rasa, aroma, warna, tekstur, dan uji hedonik terhadap penerimaan keseluruhan dapat dilihat pada Tabel 4.

\section{Warna}

Hasil uji ANOVA menunjukkan bahwa penambahan skim tidak berpengaruh terhadap warna dadih susu sapi $(\mathrm{P}<0,05)$. Nilai rata-rata warna dadih susu sapi berkisar 2,40 sampai 2,73 dengan kriteria putih kekuningan. Warna tersebut kemungkinan dipengaruhi oleh penambahan skim yang memiliki warna putih kekuningan. Sedangkan susu yang digunakan berwarna putih, sehingga terjadi perubahan warna dari putih menjadi putih kekuningan. 
Tabel 4. Nilai rata-rata uji skoring aroma, rasa, warna, tekstur dan uji hedonik penerimaan keseluruhan dadih susu sapi yang dibuat dalam tabung bambu wuluh di Bali.

\begin{tabular}{cccccc}
\hline \multirow{2}{*}{$\begin{array}{c}\text { Perlakuan } \\
\text { penambahan skim }\end{array}$} & Warna & Aroma & Tekstur & Rasa & Penerimaan Keseluruhan \\
\cline { 2 - 6 } & $2,40 \mathrm{a}$ & $2,73 \mathrm{a}$ & $3,53 \mathrm{a}$ & $2,13 \mathrm{a}$ & $2,80 \mathrm{a}$ \\
$\mathbf{S 1}(\mathbf{4 \%})$ & $2,46 \mathrm{a}$ & $2,73 \mathrm{a}$ & $3,73 \mathrm{a}$ & $2,40 \mathrm{ab}$ & $3,80 \mathrm{ab}$ \\
S2 (6\%) & $2,73 \mathrm{a}$ & $3,26 \mathrm{~b}$ & $3,80 \mathrm{a}$ & $2,60 \mathrm{~b}$ & $4,06 \mathrm{~b}$ \\
$\mathbf{S 3}(\mathbf{8 \% )}$ & $2,53 \mathrm{a}$ & $3,60 \mathrm{bc}$ & $3,80 \mathrm{a}$ & $3,40 \mathrm{c}$ & $3,33 \mathrm{ab}$ \\
$\mathbf{S 4}(\mathbf{1 0 \%})$ & $2,73 \mathrm{a}$ & $3,66 \mathrm{c}$ & $3,80 \mathrm{a}$ & $3,73 \mathrm{c}$ & $3,20 \mathrm{a}$ \\
$\mathbf{S 5}(\mathbf{1 2 \%})$ &
\end{tabular}

Keterangan : huruf yang sama dibelakang nilai rata-rata menunjukkan perlakuan tidak berbeda nyata $(\mathrm{P}>0,05)$.

\section{Aroma}

Hasil uji ANOVA menunjukkan bahwa penambahan skim berpengaruh terhadap aroma dadih susu sapi $(\mathrm{P}<0,01)$. Nilai tertinggi ditunjukkan pada perlakuan S5 yaitu 3,66 (khas susu asam) dan nilai terendah ditunjukkan pada S1 yaitu 2,73 (agak khas susu asam). Dadih memiliki aroma khas susu asam. Aroma asam berasal dari fementasi laktosa yang dipecah oleh BAL yang menghasilkan asam laktat. Asam laktat mempengaruhi flavour asam pada dadih. sehingga semakin tinggi aktivitas BAL akibat penambahan skim maka asam laktat yang dihasilkan juga semakin banyak dan aroma asam juga meningkat.

\section{Tekstur}

Hasil uji ANOVA menunjukkan bahwa penambahan skim tidak berpengaruh nyata $(\mathrm{P}>0,05)$ terhadap tekstur dadih susu sapi. Nilai rata-rata tekstur dadih susu sapi berkisar 3,53 sampai 3,80 dengan kriteria tekstur padat. Secara keseluruhan pada semua perlakuan dadih yang dihasilkan memilki tekstur yang padat. Penambahan skim dapat meningkatkan protein yang terkoagulasi dalam proses fermentasi, sehingga tekstur dadih menjadi padat.

\section{Rasa}

Hasil uji ANOVA menunjukkan bahwa penambahan skim berpengaruh sangat nyata $(\mathrm{P}<0,01)$ terhadap rasa dadih susu sapi. Nilai nilai tertinggi ditunjukkan pada S5 yaitu 3,73 (asam) dan terendah ditunjukkan pada perlakuan S1 yaitu 2,13 (kurang asam). Semakin banyak skim yang ditambahkan, semakin asam rasa yang dihasilkan. Hal tersebut dikarenakan skim meningkatkan laktosa sehingga aktivitas BAL meningkat, dan nilai asam dadih susu sapi juga semakin tinggi.

\section{Penerimaan Keseluruhan}

Hasil uji ANOVA menunjukkan bahwa penambahan skim berpengaruh nyata $(\mathrm{P}<0,05)$ terhadap penerimaan keseluruhan dadih susu sapi. Nilai tertinggi ditunjukkan pada S3 yaitu 4,06 dan nilai terendah pada perlakuan S1 yaitu 2,80. Pada pelakuan S1, S2 dan S3 terjadi peningkatan nilai berurutan, dan terjadi penurunan nilai pada pelakuan S4 dan S5. Secara keseluruhan penerimaan dadih tidak disukai hingga biasa saja. Hal tersebut mungkin disebabkan karena panelis 
belum penah mencoba dadih sebelumnya, sehingga tidak mengetahui karakteristik dadih secara keseluruhan.

\section{KESIMPULAN DAN SARAN}

\section{Kesimpulan}

1. Perlakuan penambahan skim pada proses pembuatan dadih susu sapi berpengaruh terhadap rendemen, kadar air, total asam, $\mathrm{pH}$, total mikroba, total BAL dan berpengaruh tehadap aroma (khas susu asam), rasa (asam) dan penerimaan keseluruhan., tetapi tidak berpengaruh nyata terhadap warna (putih kekuningan) dan tekstur (padat).

2. Perlakuan penambahan skim sebanyak $10 \%$ menghasilkan karakteristik terbaik dengan rendemen 65,31,\%, kadar air 63,72\%, pH 5,50, total asam 1,31\%, total koloni 4,38 $\mathrm{x}$ $10^{9} \mathrm{CFU} / \mathrm{g}$, total BAL $3,42 \times 10^{9} \mathrm{CFU} / \mathrm{g}$, warna putih kekuningan, aroma khas susu asam, tekstur padat, rasa asam dan agak tidak disukai secara keseluruhan.

\section{Saran}

Berdasarkan hasil penelitian pembuatan dadih susu sapi, untu meningkatkan padatan susu sapi dapat ditambahkan skim sebanyak $10 \%$.

\section{DAFTAR PUSTAKA}

Afriani. 2008. Kualitas dan Potensi Dadih Sebagai Tambahan Pendapatan Peternak Kerbau di Kabupaten Kerinci. Jurnal Ilmu Peternakan. 11(3) : 115-120.

Alase, C. A. 1994. Pengaruh Jenis Kemasan dan Suhu Penyimpanan Terhadap Kualitas dan Daya Simpan Dadih Susu yang
Dipasteurisasi. Skripsi . Fakultas Tekologi Pertanian Bogor IPB, Bogor.

Azria, D. 1986. Mikrobiologi dalam Pembuatan Dadih Susu Sapi. Skipsi. Fakultas Teknologi Pertanian IPB. Bogor.

Coggins, J. S. 1991. Predicting Cheddar Chesse Yield in an Individual Plant. Van Slyke revisited. Journal Daily Science. 74 (2) : 359-368.

Gomes, K. A. dan A. A. Gomes. 1995. Prosedur Statistik Untuk Penelitian Pertanian. UI Press, Jakarta.

Hosono, A. 1992. Fermente, Milk in the Orient. In: Functions of Fermented Milk, Challenges for Health Science. Y. Nakazawa dan A. Hosono (ed).

Koesoemawardani. D., Samsul. R dan Moralita. T. 2013. Perubahan Sifat Mikrobiologi dan Kimiawi Rusip Selama Fermentasi. Jurnal Agritech. 33(3) : 268. Universitas Lampung, Bandar Lampung.

Legowo, A., Kusrahayu dan S. Mulyani. 2009. Ilmu dan Teknologi Susu. Universitas Diponegoro, Semarang.

Rahman, A., S. Fardiaz., W. P. Rahayu., Suliantari dan C. C. Nurwitri. 1992. Teknologi Fermentasi Susu. Pusat Antar IPB, Bogor.

Setiyanto, H., Miskiya., Abubaka., S. Usmiati., W. Broto., E. Sukasih., dan A. Edial. 2009. Perbaikan Proses dan Pengemasan Dadih Sebagai Probiotik dengan Daya Simpan Sampai 20 Hari. Laporan Penelitian. Litbang, Bogor.

Sirait, C.H. 1993. Pengolahan Susu Tradisional untuk Pekembangan Agroindustri Persusuan Di Pedesaan. Laporan Penelitian. Balai Penelitian Tenak Ciawi, Bogor.

Sugitha, I. M. 1995. "Olahan Susu Kerbau Tradisional Minang" Kendala dan Perspektif dalam Era Industrialisasi di Sumatera Barat. Seminar Sehari THT Fakultas Pternakan Unand, Padang.

Usmiati, S dan Risfaheri. 2013. Pengembangan Dadih Sebagai Pangan Fungsional 
Probiotik Asli Sumatera Barat. Jurnal Litbang Peternakan. 32(1) : 20-29.

Wijayanti, M. D. S., Imam T., Puwadi. 2016. Kualitas Dadih Susu Kambing yang Diinkubasi pada Berbagai Macam Bambu. Jurnal Ilmu dan Teknologi Hasil Ternak Universitas Brawijaya. 11(1) : 22-23.
Yudoamijoyo, R. M., T. Zoelfikar., S. R. Herastuti., A. Tomomatsu., A. Matsuyama., A. Ozono. 1983. Chemical and Microbiological Aspect of Dadih in Indonesia. Japanese Journal Dairy Food Science.
$32(1)$
1-10. 